\title{
METHOD DEVELOPMENT AND VALIDATION FOR THE SIMULTANEOUS DETERMINATION OF METOPROLOL AND ATORVASTATIN BY REVERSED-PHASE HIGH-PERFORMANCE LIQUID CHROMATOGRAPHY IN ITS BULK AND PHARMACEUTICAL TABLET DOSAGE FORM USING BIORELEVANT DISSOLUTION MEDIA (FASTED STATE SMALL INTESTINAL FLUID)
}

\author{
PALANI SHANMUGASUNDARAM ${ }^{1 *}$, KAMARAPU SK ${ }^{2}$ \\ ${ }^{1}$ Department of Pharmaceutical Chemistry and Analysis, School of Pharmaceutical Sciences, Vels Institute of Science, Technology and \\ Advanced Studies, Chennai, Tamil Nadu, India. ${ }^{2}$ Department Pharmaceutical Analysis, School Pharmaceutical Sciences, Vels Institute of \\ Science, Technology and Advanced Studies, Chennai, Tamil Nadu, India. Email: samsimahi@gmail.com
}

Received: 10 October 2018, Revised and Accepted: 10 December 2018 and 11 December 2018

ABSTRACT

Objective: A present investigation is based on method development and validation for the simultaneous determination of metoprolol and atorvastatin by reversed-phase high-performance liquid chromatography in its bulk and pharmaceutical dosage form using a biorelevant dissolution media (fasted state small intestinal fluid).

Methods: The chromatographic separation technique performed by an isocratic method for this column used Inertsil oDS-3 ( $4.6 \times 150 \mathrm{~mm}, 5 \mu \mathrm{m})$. The ratio of mobile phase used is phosphate buffer $4.8 \mathrm{pH}$ : acetonitrile $(35: 65 \mathrm{v} / \mathrm{v})$, flow rate $1 \mathrm{ml} / \mathrm{min}$, and analysis time $15.0 \mathrm{~min}$, UV detection was at $244 \mathrm{~nm}$.

Results: According to the International Conference on Harmonisation Q2 (R1) guidelines, the method validation was done. Peaks were observed at $2.227 \mathrm{~min}$ and $5.819 \mathrm{~min}$, concentration range of linearity was obtained at $50-250 \mu \mathrm{g} / \mathrm{ml}$ and $10-50 \mu \mathrm{g} / \mathrm{ml}$, linearity correlation coefficients were 0.9997 and 0.9995 , limit of detection was $0.33 \mathrm{mg} / \mathrm{ml}$ and $0.21 \mathrm{mg} / \mathrm{ml}$, and limit of quantification was $1.08 \mathrm{mg} / \mathrm{ml}$ and $0.69 \mathrm{mg} / \mathrm{ml}$ for metoprolol and atorvastatin, respectively.

Conclusion: The obtained results for this method validation are within acceptance criteria. This method was more economical and stable for routine analysis.

Keywords: Metoprolol and atorvastatin, Reversed-phase high-performance liquid chromatography, Method development, Validation, International Conference on Harmonisation Q2 (R1), Biorelevant dissolution media (fasted state small intestinal fluid).

(C) 2018 The Authors. Published by Innovare Academic Sciences Pvt Ltd. This is an open access article under the CC BY license (http://creativecommons. org/licenses/by/4. 0/) DOI: http://dx.doi.org/10.22159/ajpcr.2018.v11s4.31675

\section{INTRODUCTION}

Metoprolol acts as a competitive $\beta 1$-adrenergic receptor antagonist agent [1,2] (cardioselective) used as the antihypertensive agent. Antagonist activity of this agent is mainly because of more substituents present on the para position [3,4]. It shows membrane-stabilizing effects prescribed at a high dose than the dose required to show antagonist property [5]. The IUPAC name for metoprolol is 1-[4-(2-methoxyethyl] phenoxy]-3-(propan-2-ylamino)propan-2-ol. Chemical structure for metoprolol is shown in Fig. 1.

Atorvastatin is a statin and used as the lipid-lowering agent. It decreases the cholesterol levels by inhibiting the 3-hydroxy-3-methylglutaryl (HMG)-CoA enzyme because, in mevalonate pathway, it is a ratedetermining enzyme in cholesterol. Atorvastatin primarily [6,7] acts on the liver and selectively inhibits the release of HMG-CoA reductase enzyme. HMG-CoA reductase is responsible for converting HMG-CoA to mevalonate in the cholesterol biosynthesis, and by this enzyme, conversion reaction prevents the synthesis of hepatic cholesterol [7-9]. It will encourage the hepatic uptake of cholesterol and decreases serum cholesterol levels by stimulation of hepatic low-density lipoproteincholesterol receptors [10]. The IUPAC name for atorvastatin is (3R, 5R)-7-[2-(4-fluorophenyl)-3-phenyl-4-(phenylcarbamoyl)-5-propan2-ylpyrrol-1-yl]-3,5-dihydroxyheptanoic acid. Chemical structure for Atorvastatin is shown in Fig. 2.

From literature review [11-26], we found that there were no methods available for simultaneous determination of metoprolol and atorvastatin in a combined dosage form by reversed-phase high-performance liquid chromatography (RP-HPLC) using biorelevant dissolution media. This research work denotes a novel, economical, accurate, precise, specific, robust, rugged RP-HPLC method developed in the selected solvent system (mobile phase) in biorelevant dissolution media (fasted state small intestinal fluid [FaSSIF]) [27-31], and the validation was performed as per the International Conference on Harmonisation (ICH) Q2 (R1) guidelines [32].

\section{MATERIALS AND METHODS}

\section{Reagents and chemicals}

The metoprolol and atorvastatin pure standards were supplied by Syncorp Clincare Pvt. Ltd., Dilsuknagar, Hyderabad. The marketed formulation tablets labeled to contain $50 \mathrm{mg}$ of metoprolol and $10 \mathrm{mg}$ of atorvastatin, manufactured by Emcure Pharmaceuticals Ltd. (Metpure St), were obtained from the market. Analytical reagent grade and HPLC Grade chemicals procured from SD Fine-Chem Ltd., Mumbai (Mumbai, India) were used in the research.

\section{Instruments used}

The instrument was used Waters HPLC (717 series), Inertsil ODS-3 column, UV detector, data handling system EMPOWER2 software, UVVisible double beam spectrophotometer (Labindia), analytical balance $0.1 \mathrm{mg}$ sensitivity (SHIMADZU), pH meter (Labindia), and ultrasonicator.

\section{Blank FaSSIF}

Weigh and dissolve $\mathrm{NaOH}$ (1.74 g), $\mathrm{NaH}_{2} \mathrm{PO}_{4}(19.77 \mathrm{~g})$, and $\mathrm{NaCl}$ ( $30.93 \mathrm{~g}$ ) in $5 \mathrm{~L}$ of HPLC grade distilled, and the $\mathrm{pH}$ was adjusted to 6.5 by using $1 \mathrm{~N} \mathrm{HCl}$. 


\section{Diluent}

Weigh and dissolve $3.3 \mathrm{~g}$ sodium taurocholate in approximately $500 \mathrm{ml}$ of blank FaSSIF. Then, add $11.8 \mathrm{ml}$ of methylene chloride solution containing $100 \mathrm{mg} / \mathrm{ml}$ of lecithin, and it produces an emulsion which is turbid. This solution was subjected to vacuum at a temperature of about $40^{\circ} \mathrm{C}$ under pressure at $500 \mathrm{mbar}$ for $10 \mathrm{~min}$ and followed by $30 \mathrm{~min}$ at 10 mbar to get a clear solution. After that the solution was cooled to $27^{\circ} \mathrm{C}$ and make up the volume to $2 \mathrm{~L}$ with blank FaSSIF.

\section{Stock solutions}

Weigh and transfer pure $10 \mathrm{mg}$ of metoprolol and atorvastatin separately into $10 \mathrm{ml}$ volumetric flasks. Then, add $7 \mathrm{ml}$ of diluent and ultrasonicated for $15 \mathrm{~min}$. Filter the solution using membrane filter paper $(0.45 \mu \mathrm{m})$, and volume make up to $10 \mathrm{ml}$ using the same diluent. Five levels of linearity concentrations were prepared by mixed appropriately and further diluted to get $50-250 \mu \mathrm{g} / \mathrm{ml}$ of metoprolol and $10-50 \mu \mathrm{g} / \mathrm{ml}$ of atorvastatin. Inject the series concentrations in triplicate into the column, and the average peak areas are recorded from chromatograms. Linearity graph was plotted peak area against concentrations.

\section{Mixed working solution}

To prepare separately $1 \mathrm{mg} / \mathrm{ml}$ of metoprolol and atorvastatin solution by using stock solution. From this above solutions, pipette out $1 \mathrm{ml}$ of metoprolol solution and $0.1 \mathrm{ml}$ of atorvastatin solution into a $10 \mathrm{ml}$ volumetric flask and make up the volume with a diluent, to get concentrations $100 \mu \mathrm{g} / \mathrm{ml}$ and $10 \mu \mathrm{g} / \mathrm{ml}$ of metoprolol and atorvastatin working solutions, respectively.

\section{Test solution}

According to I.P method, take twenty tablets and weighed. Then, the tablets are triturated in a mortar to get smooth powder. The amount of drug present in a powder which is equivalence to standard drug of $10 \mathrm{mg}$ of atorvastatin. The powder was transferred to a $100 \mathrm{ml}$ of volumetric flask and add approximately $70 \mathrm{ml}$ of diluent, and the resulted solution was subjected to sonication for $15 \mathrm{~min}$ by using ultrasonicator, Then, the solution was filtered using membrane filter paper $(0.45 \mu \mathrm{m})$ and volume make up to $100 \mathrm{ml}$ using the same diluent. From this, take $1 \mathrm{ml}$ and transfer to six $10 \mathrm{ml}$ volumetric flasks, and then, the volume was made up mark with the diluent. These solutions are injected 3 times each sample solution into the column and the results are mentioned as a function of mean of all replicas.

\section{Study of spectra and selection of wavelength}

Working standard solutions were scanned an entire range of UV in a $1 \mathrm{~cm}$ cell against blank using UV-spectrophotometer. The absorption maxima of metoprolol and atorvastatin were selected from spectral data, and isosbestic wavelength was selected from overlain spectra of UV spectrophotometer. An isosbestic point was found to be at $244 \mathrm{~nm}$. The UV spectrum of metoprolol and atorvastatin is shown in Fig. 3.

\section{Optimization of HPLC method}

The column used in this method was performed on Inertsil ODS$3(4.6 \times 150 \mathrm{~mm}, 5 \mu \mathrm{m})$. The method was optimized with a mobile phase as its composition phosphate buffer $4.8 \mathrm{pH}$ and acetonitrile (35:65v/v) that run isocratically; conditions were optimized with the rate at which mobile phase runs at $1.0 \mathrm{ml} / \mathrm{min}$, UV detection at $244 \mathrm{~nm}$, and analysis time was $15.0 \mathrm{~min}$.

\section{Validation of method}

This method was validated according to the ICH Q2 (R1) guidelines. The validation parameters performed were system suitability, linearity range, accuracy data, precision (intra and inter), limit of detection (LOD), limits of quantification (LOQ), and robustness.

\section{Forced degradation studies}

Active pharmaceutical ingredients of metoprolol and atorvastatin were subjected to keep in degradation ways and find the extent of degradation of a product by this method. The parameters were carried out for forced degradation studies are acid, base, peroxide, thermal and photo degradation.

\section{RESULTS AND DISCUSSION}

Method development and optimized method

This method was accurate, specific, linear, precise, and suitable for the analysis of metoprolol and atorvastatin by RP-HPLC method. The HPLC instrument comprised a Waters HPLC with autosampler and UV detector. The Inertsil ODS-3 $(4.6 \times 150 \mathrm{~mm}, 5 \mu \mathrm{m})$ column is used. The ratio of mobile phase used is phosphate buffer $4.8 \mathrm{pH}$ : acetonitrile $(35: 65 \mathrm{v} / \mathrm{v})$. Mode of separation is isocratic and its temperature of the column is ambient. The optimized chromatographic conditions are mentioned in Table 1 and chromatograms are shown in Figs. 4-7.

\section{Assay}

The assay study was performed for the metoprolol and atorvastatin in marketed tablet dosage form. For each determination, 3 times inject the solution into the column. The assay chromatogram is shown in Fig. 8 and the results are mentioned in Table 2 .

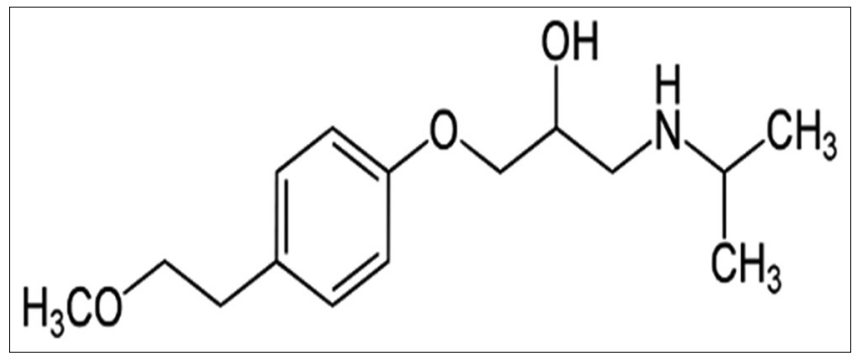

Fig. 1: Chemical structure of metoprolol

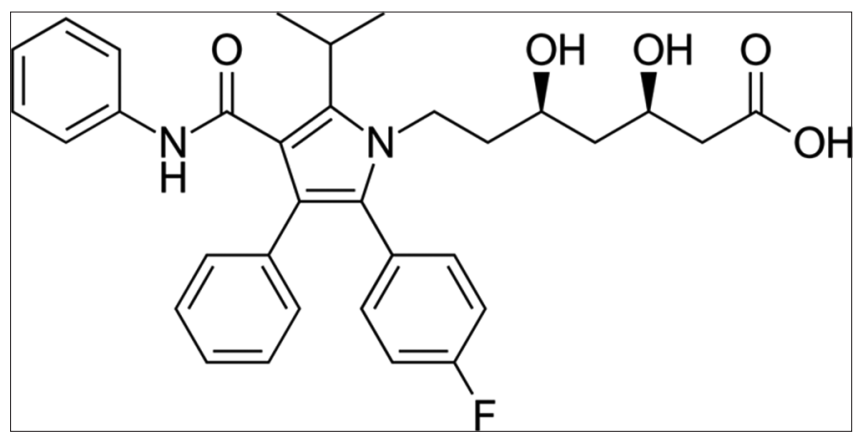

Fig. 2: Chemical structure of atorvastatin

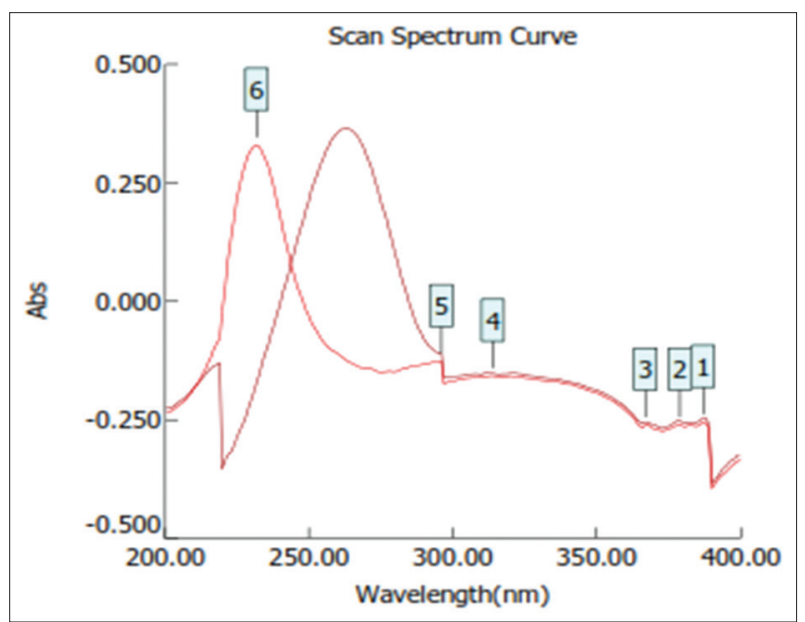

Fig. 3: Overlay spectrum for isosbestic point 
Table 1: Optimized conditions

\begin{tabular}{ll}
\hline Optimization parameters & Method conditions \\
\hline Stationary phase & Inertsil ODS-3 $(4.6 \times 150 \mathrm{~mm}, 5 \mu \mathrm{m})$ \\
Mobile phase & $\begin{array}{l}\text { Phosphate buffer } 4.8 \mathrm{pH} \text { and } \\
\text { acetonitrile }(35: 65 \mathrm{v} / \mathrm{v})\end{array}$ \\
$\mathrm{pH}$ & $4.8 \pm 0.02$ \\
Flow rate & $1.0 \mathrm{ml} / \mathrm{min}$ \\
Analysis time each injection & $15.0 \mathrm{~min}$ \\
Temperature of column & Ambient ${ }^{\circ} \mathrm{C}$ \\
Fixed injection loop volume & $20 \mu \mathrm{l}$ \\
Detection wavelength & $244 \mathrm{~nm}$ \\
Drugs retention time & 2.227 and $5.819 \mathrm{~min}$ \\
\hline
\end{tabular}

\section{Method validation}

This method was validated according to the ICH Q2 (R1) guidelines for various parameters.

\section{Suitability}

The mixed working solution was injected six replicates into the chromatographic column. The mean of suitability parameters was calculated from the obtained chromatogram. Results are tabulated in Tables 3 and 4.

\section{Linearity and range}

The linearity study was performed for the series concentrations $50-250 \mu \mathrm{g} / \mathrm{ml}$ and $10-50 \mu \mathrm{g} / \mathrm{ml}$ of metoprolol and atorvastatin,

Table 2: Assay data for marketed tablets

\begin{tabular}{llll}
\hline Tablet (Metpure St) & Label claim (mg) & Amount estimated* (mg) & Amount estimated (\%) \\
\hline Metoprolol & 50 & 50.05 & 100.10 \\
Atorvastatin & 10 & 10.06 & 100.66 \\
\hline
\end{tabular}

*Mean of three determinations

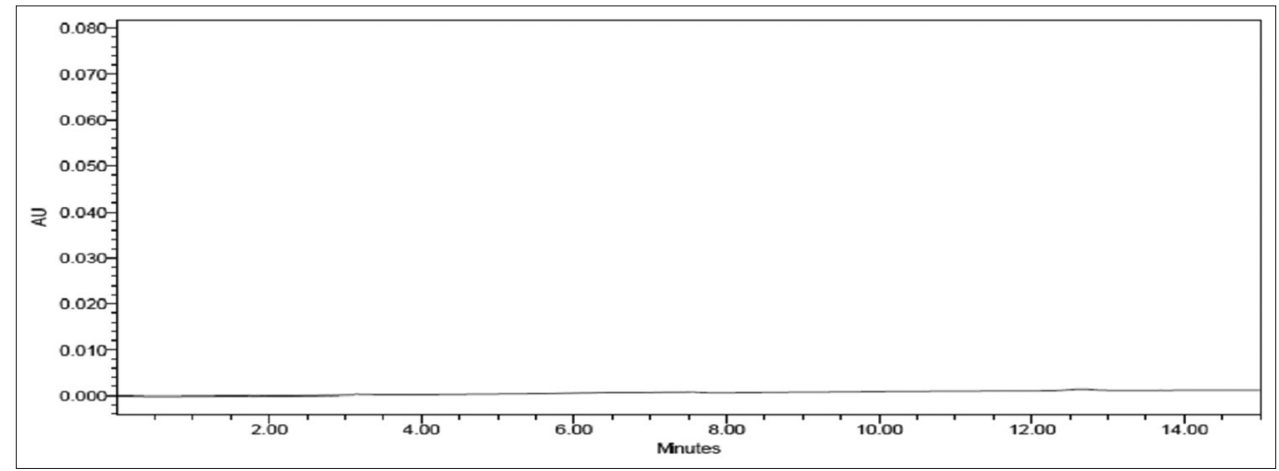

Fig. 4: Chromatogram for blank preparation

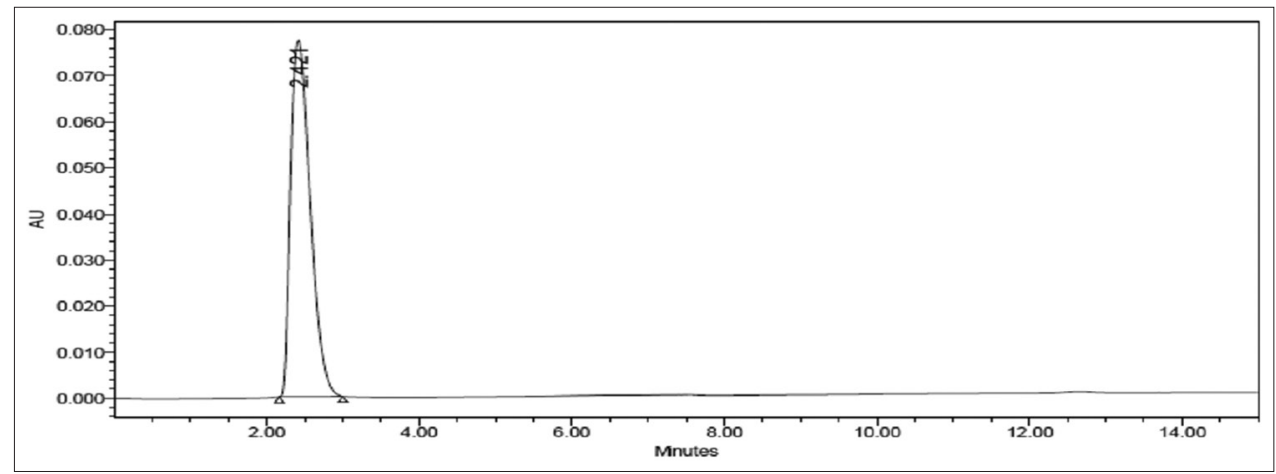

Fig. 5: Chromatogram for standard metoprolol

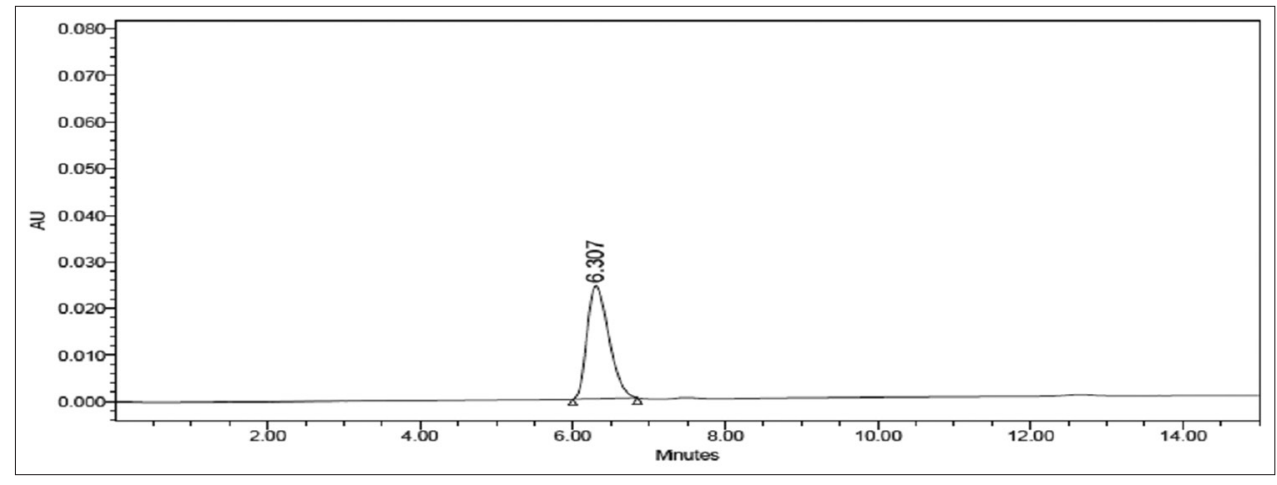

Fig. 6: Chromatogram for standard atorvastatin 
respectively. The obtained values are tabulated in Tables 5 and 6 . The graph for both the drugs is shown in Figs. 9-10 and overlay chromatogram in Fig. 11.

Accuracy

The accuracy study was performed for 80,100 , and $120 \%$ for metoprolol and atorvastatin. Each level was injected in triplicate into a chromatographic column. The area of each level was used for calculation of \% recovery drug. The results are tabulated in Tables 7 and 8.

\section{Table 3: System suitability for metoprolol and atorvastatin}

\begin{tabular}{lll}
\hline Parameter & Metoprolol & Atorvastatin \\
\hline Retention time (min) & 2.227 & 5.819 \\
Resolution (Rs. >2) & 3.11 & 3.19 \\
Asymmetry (T£2) & 0.14 & 0.29 \\
Theoretical plates & 3941 & 2843 \\
Tailing factor & 1.54 & 1.84 \\
\hline
\end{tabular}

Precision

The study of precision in this method was based on intraday and interday variations. The working standard solutions of metoprolol and atorvastatin have injected six replicas on the same day and on three different days for three different levels of concentrations. The mean and percentage relative standard deviation (\% RSD) are tabulated in Tables 9 and 10. The results obtained all are within acceptable limits (\% RSD <2).

\section{$L O D$ and $L O Q$}

For metoprolol and atorvastatin, LOD was found to be $0.33 \mathrm{mg} / \mathrm{ml}$ and $0.21 \mathrm{mg} / \mathrm{ml}$ and LOQ was found to be $1.08 \mathrm{mg} / \mathrm{ml}$ and $0.69 \mathrm{mg} / \mathrm{ml}$, respectively. The obtained values are tabulated in Table 11.

\section{Robustness}

It is a prediction of reliability for method development to maintain stable and unaffected the results are obtained by small changes

Table 4: System suitability (peak area and Rt) for metoprolol and atorvastatin

\begin{tabular}{llll}
\hline Injection & Peak area for metoprolol & Peak area for atorvastatin & Rt for metoprolol \\
\hline Injection-1 & $1,235,278$ & 436,704 & 2.216 \\
Injection-2 & $1,220,850$ & 435,672 & 2.223 \\
Injection-3 & $1,239,231$ & 439,902 & 2.217 \\
Injection-4 & $1,212,072$ & 435,887 & 2.228 \\
Injection-5 & $1,237,137$ & 442,806 & 2.214 \\
Injection-6 & $1,228,702$ & 444,747 & 2.223 \\
Average & $1,228,878.3$ & 439286.3 & 2.220 \\
Standard deviation & 10613.9 & 3843.8 & 0.00534478 \\
\% RSD & 0.9 & 0.9 & 5.831 \\
\hline
\end{tabular}

Rt: Retention time, RSD: Relative standard deviation

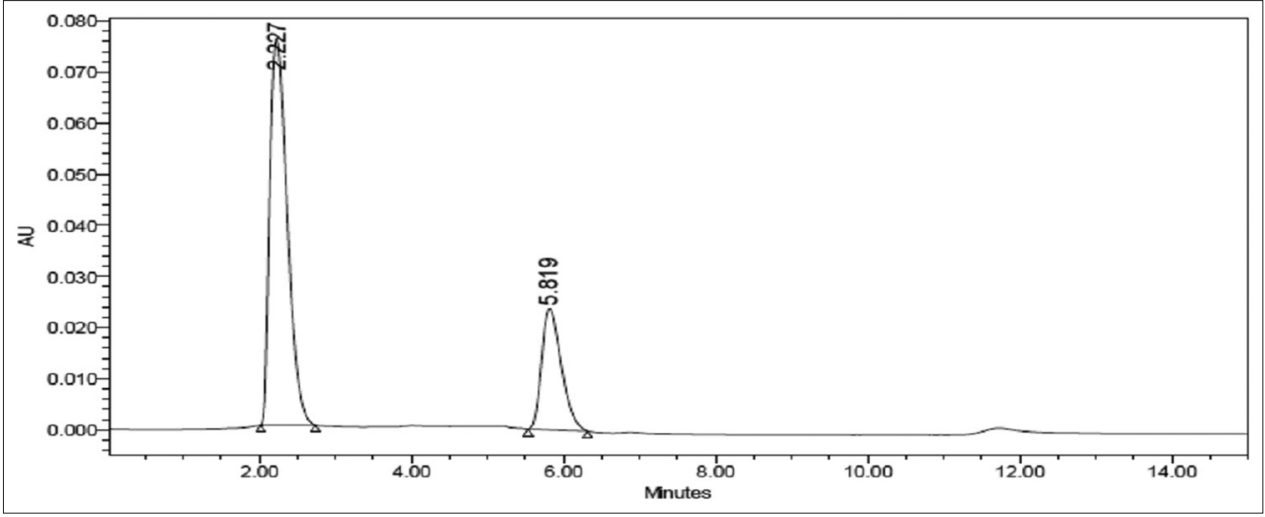

Fig. 7: Chromatogram for mixed standard metoprolol and atorvastatin at $244 \mathrm{~nm}$ from bulk drug

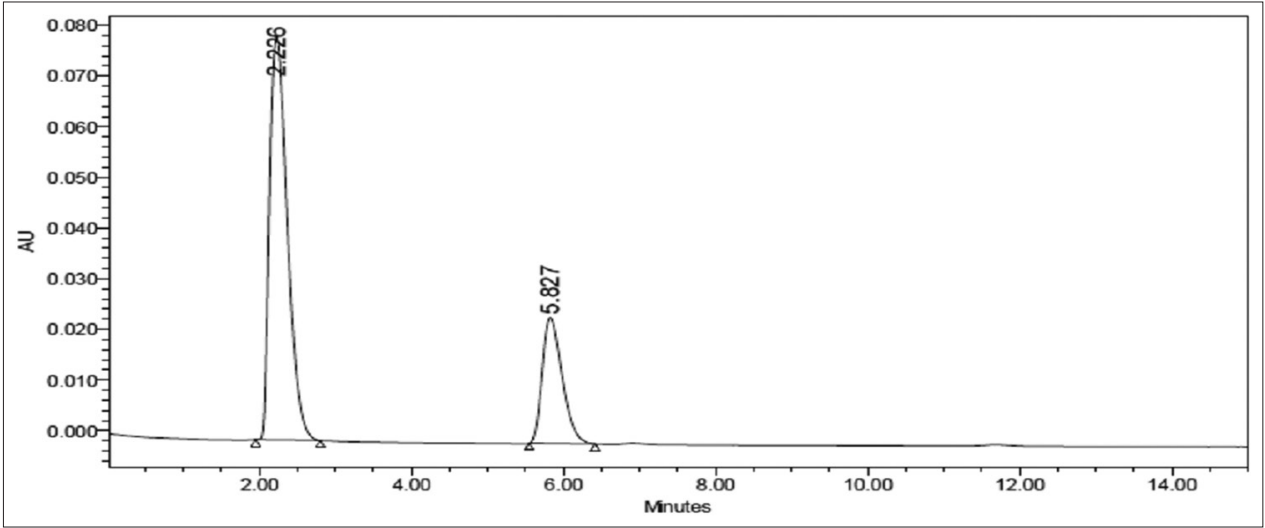

Fig. 8: Chromatogram for metoprolol and atorvastatin at $244 \mathrm{~nm}$ from pharmaceutical dosage form (Metpure St) 
Table 5: Linearity results: (For metoprolol)

\begin{tabular}{lll}
\hline S. No & Linearity concentration $(\mu \mathrm{g} / \mathbf{m l})$ & Peak area \\
\hline 1 & 50 & 424,986 \\
2 & 100 & 821,489 \\
3 & 150 & $1,243,214$ \\
4 & 200 & $1,614,178$ \\
5 & 250 & $2,019,024$ \\
Correlation coefficient & & 0.9997 \\
\hline
\end{tabular}

Table 6: Linearity results: (For atorvastatin)

\begin{tabular}{lll}
\hline S. No & Linearity concentration $(\boldsymbol{\mu g} / \mathbf{m l})$ & Peak area \\
\hline 1 & 10 & 144,310 \\
2 & 20 & 297,966 \\
3 & 30 & 437,053 \\
4 & 40 & 572,746 \\
5 & 50 & 724,791 \\
Correlation coefficient & & 0.9995 \\
\hline
\end{tabular}

Table 7: Accuracy data for metoprolol

\begin{tabular}{|c|c|c|c|c|}
\hline \multirow[t]{2}{*}{ Sample Id } & \multicolumn{2}{|c|}{ Concentration $(\mu \mathrm{g} / \mathrm{ml})$} & \multirow[t]{2}{*}{ \% Recovery } & \multirow[t]{2}{*}{ Statistical data } \\
\hline & Pure drug & Amount added & & \\
\hline $\mathrm{S}_{1}: 80 \%$ & 80 & 100 & 100.19 & Mean $=100.17 \%$ \\
\hline $\mathrm{S}_{2}: 80 \%$ & 80 & 100 & 100.17 & $\mathrm{SD}=0.200083$ \\
\hline $\mathrm{S}_{3}^{2}: 80 \%$ & 80 & 100 & 100.16 & $\% \mathrm{RSD}=0.202152$ \\
\hline $\mathrm{S}_{4}: 100 \%$ & 100 & 100 & 100.39 & Mean=100.40\% \\
\hline$S_{5}: 100 \%$ & 100 & 100 & 100.4 & $\mathrm{SD}=0.33$ \\
\hline $\mathrm{S}_{7}: 120 \%$ & 120 & 100 & 100.67 & Mean $=100.68 \%$ \\
\hline $\mathrm{S}_{8}^{\prime}: 120 \%$ & 120 & 100 & 100.71 & $\mathrm{SD}=0.33$ \\
\hline$S_{9}^{8}: 120 \%$ & 120 & 100 & 100.68 & $\% \mathrm{RSD}=0.331159$ \\
\hline
\end{tabular}

RSD: Relative standard deviation

Table 8: The accuracy data for atorvastatin

\begin{tabular}{|c|c|c|c|c|}
\hline \multirow[t]{2}{*}{ Sample Id } & \multicolumn{2}{|c|}{ Concentration $(\mu \mathrm{g} / \mathrm{ml})$} & \multirow[t]{2}{*}{ \% Recovery } & \multirow[t]{2}{*}{ Statistical data } \\
\hline & Pure drug & Amount added & & \\
\hline $\mathrm{S}_{1}: 80 \%$ & 80 & 100 & 100.61 & Mean $=100.62 \%$ \\
\hline $\mathrm{S}_{2}: 80 \%$ & 80 & 100 & 100.64 & $\mathrm{SD}=0.198578$ \\
\hline $\mathrm{S}_{3}^{2}: 80 \%$ & 80 & 100 & 100.62 & $\% \mathrm{RSD}=0.199884$ \\
\hline$S_{4}^{3}: 100 \%$ & 100 & 100 & 100.84 & Mean=100.84\% \\
\hline $\mathrm{S}_{5}: 100 \%$ & 100 & 100 & 100.81 & $\mathrm{SD}=0.032146$ \\
\hline$S_{6}: 100 \%$ & 100 & 100 & 100.89 & $\% \mathrm{RSD}=0.03242$ \\
\hline$S_{7}^{0}: 120 \%$ & 120 & 100 & 100.41 & Mean=100.40\% \\
\hline $\mathrm{S}_{8}^{\prime}: 120 \%$ & 120 & 100 & 100.46 & $\mathrm{SD}=0.040415$ \\
\hline$S_{9}^{8}: 120 \%$ & 120 & 100 & 100.45 & $\% \mathrm{RSD}=0.04068$ \\
\hline
\end{tabular}

Table 9: Intraday and interday precision for metoprolol standard solutions

\begin{tabular}{lllllll}
\hline \multirow{2}{*}{ Concentration $(\mu \mathrm{g} / \mathrm{ml})$} & \multicolumn{2}{l}{ Results } & & \\
\cline { 2 - 3 } & \multicolumn{2}{l}{ Intraday } & & & \multicolumn{2}{l}{ Interday } \\
\cline { 2 - 3 } \cline { 5 - 6 } & Mean & \% RSD & & Mean & \% RSD \\
\hline 80 & 80.04 & 0.24 & & 79.76 & 0.22 \\
100 & 100.45 & 0.35 & & 100.12 & 0.33 \\
120 & 119.16 & 0.15 & & 120.20 & 0.18 \\
\hline
\end{tabular}

were made in method development. The robustness data conducted for variations in flow rate and percentage of composition in the
Table 10: Intraday and interday precision for atorvastatin standard solutions

\begin{tabular}{llllll}
\hline Concentration $(\mu \mathrm{g} / \mathrm{ml})$ & \multicolumn{2}{l}{ Results } & & \\
\cline { 2 - 3 } & \multicolumn{2}{l}{ Intraday } & & & \multicolumn{2}{l}{ Interday } \\
\cline { 2 - 3 } \cline { 5 - 6 } & Mean & \% RSD & & Mean & \% RSD \\
\hline 80 & 80.05 & 1.02 & & 79.59 & 0.98 \\
100 & 99.94 & 0.74 & & 100.09 & 0.56 \\
120 & 119.97 & 0.35 & & 120.006 & 0.32 \\
\hline
\end{tabular}

RSD: Relative standard deviation

mobile phase were performed. The obtained values are tabulated in Tables 12-13. 
Asian J Pharm Clin Res, Vol 11, Special Issue 4, 2018, 1-8

Forced degradation studies

The data obtained in forced degradation studies reveal that the developed method is more stable in some stress conditions. Metoprolol was stable in thermal and photolytic (degradation) stress conditions, and the atorvastatin was comparatively stable in oxidation degradation. The obtained values are tabulated in Table 14, and chromatograms are shown in Figs. 12-16.

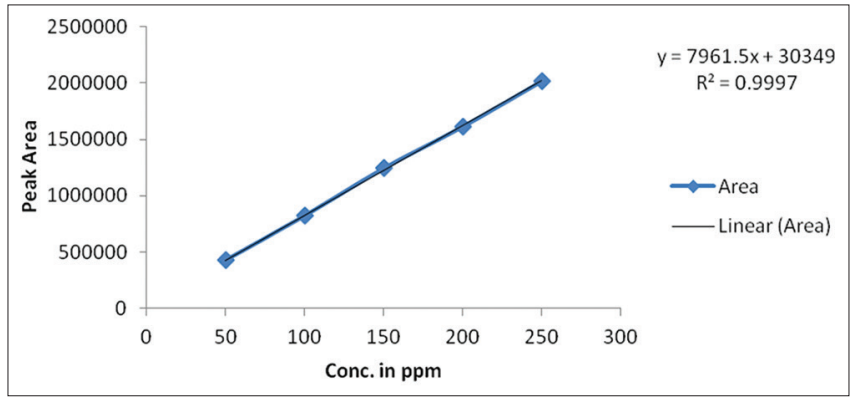

Fig. 9: Calibration curve of metoprolol

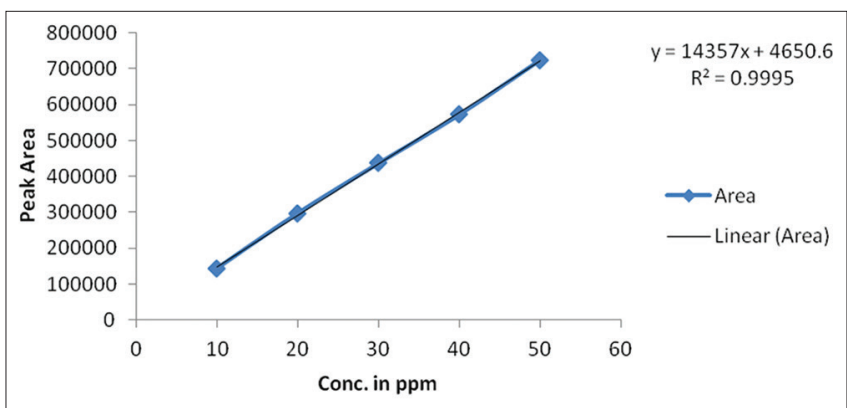

Fig. 10: Calibration curve of atorvastatin

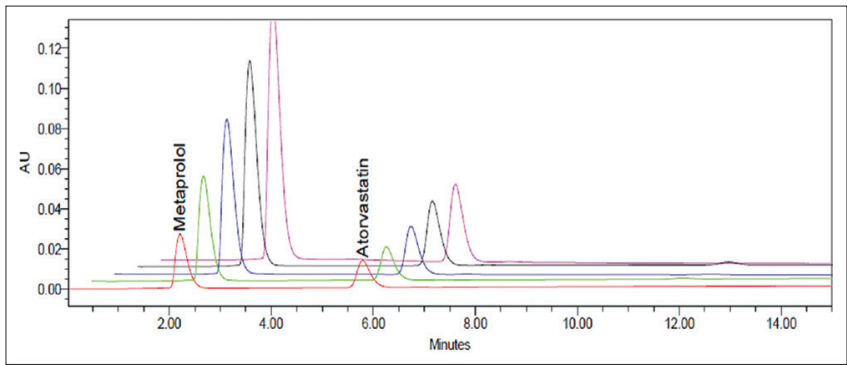

Fig. 11: Overlay report for linearity
CONCLUSION

Table 11: LOD and LOQ for metoprolol and atorvastatin

\begin{tabular}{lll}
\hline Parameter & Metoprolol & Atorvastatin \\
\hline LOD & 0.33 & 0.21 \\
LOQ & 1.08 & 0.69 \\
\hline LOD: Limit of detection, LOQ: Limits of quantification &
\end{tabular}

Table 12: Robustness data for variation in flow rate

\begin{tabular}{llll}
\hline Drug & Flow rate $(\mathrm{ml} / \mathrm{min})$ & \multicolumn{2}{l}{ System suitability } \\
\cline { 3 - 4 } & & $\begin{array}{l}\text { Tailing } \\
\text { factor }\end{array}$ & $\begin{array}{l}\text { Theoretical } \\
\text { plates }\end{array}$ \\
\hline Metoprolol & 0.9 & 1.53 & 3391.33 \\
& $* 1$ & 1.56 & 3399.02 \\
Atorvastatin & 1.1 & 1.57 & 3418.14 \\
& 0.9 & 1.82 & 2803.28 \\
& 1.1 & 1.84 & 2843.08 \\
& & 1.86 & 2892.46 \\
\hline
\end{tabular}

*Results from assay standard

Table 13: Robustness data for variation in percentage of composition in the mobile phase

\begin{tabular}{|c|c|c|c|}
\hline \multirow[t]{2}{*}{ Drug } & \multirow{2}{*}{$\begin{array}{l}\text { Percentage of } \\
\text { composition in the } \\
\text { mobile phase }\end{array}$} & \multicolumn{2}{|c|}{ System suitability } \\
\hline & & $\begin{array}{l}\text { Tailing } \\
\text { factor }\end{array}$ & $\begin{array}{l}\text { Theoretical } \\
\text { plates }\end{array}$ \\
\hline \multirow[t]{3}{*}{ Metoprolol } & $10 \%$ less & 1.55 & 3445.74 \\
\hline & *Actual & 1.56 & 3399.02 \\
\hline & $10 \%$ more & 1.52 & 3427.53 \\
\hline \multirow[t]{3}{*}{ Atorvastatin } & $10 \%$ less & 1.43 & 5082.74 \\
\hline & *Actual & 1.36 & 5167.98 \\
\hline & $10 \%$ more & 1.43 & 5667.09 \\
\hline
\end{tabular}

*Results from assay standard

Table 14: Degradation results for metoprolol and atorvastatin

\begin{tabular}{llllll}
\hline Sample name & \multicolumn{2}{l}{ Metoprolol } & & \multicolumn{2}{l}{ Atorvastatin } \\
\cline { 2 - 3 } \cline { 5 - 6 } & Area & \% Degraded & & Area & \% Degraded \\
\hline Standard & 1214803 & & & & \\
& 1196736 & 1.49 & 416562 & \\
Acid & 1175633 & 3.22 & & 410776 & 3.68 \\
Base & 1097863 & 9.63 & & 407623 & 4.42 \\
Peroxide & 1167563 & 3.89 & 403572 & 5.37 \\
Thermal & 1165552 & 4.05 & 398772 & 6.50 \\
Photo & & & & \\
\hline
\end{tabular}

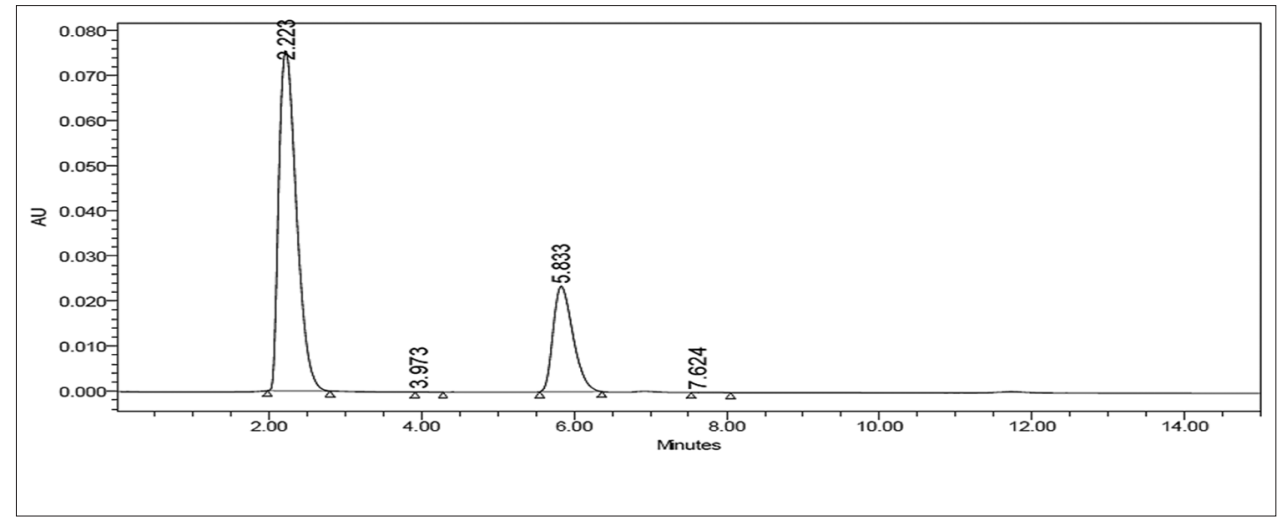

Fig. 12: Acidic degradation 


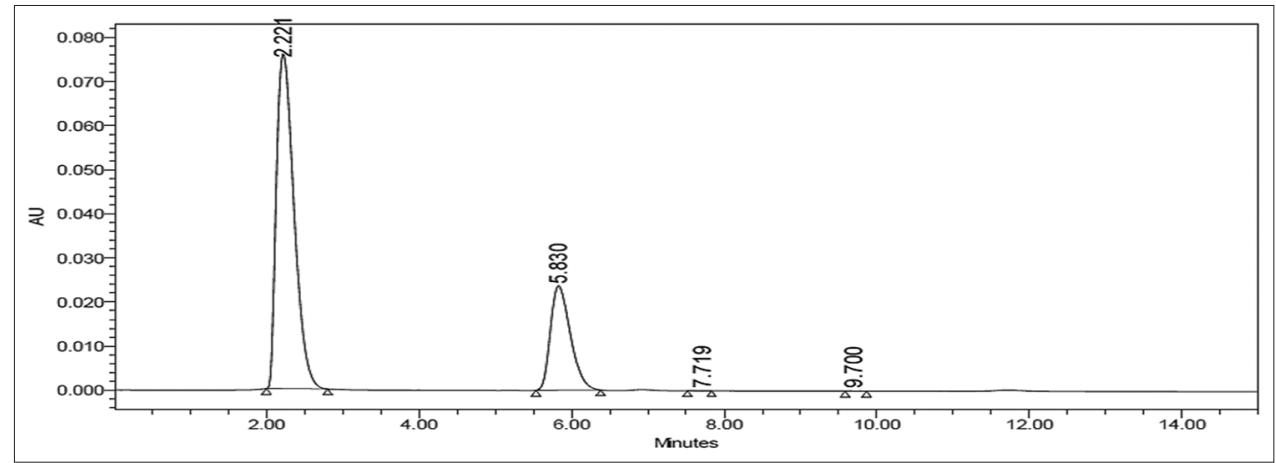

Fig. 13: Alkaline degradation

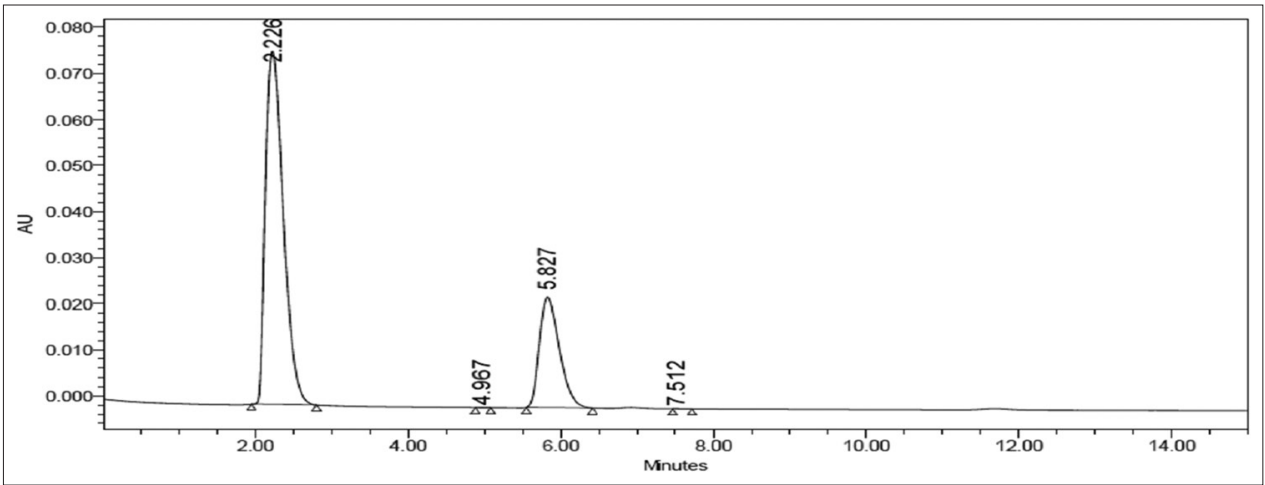

Fig. 14: Thermal degradation

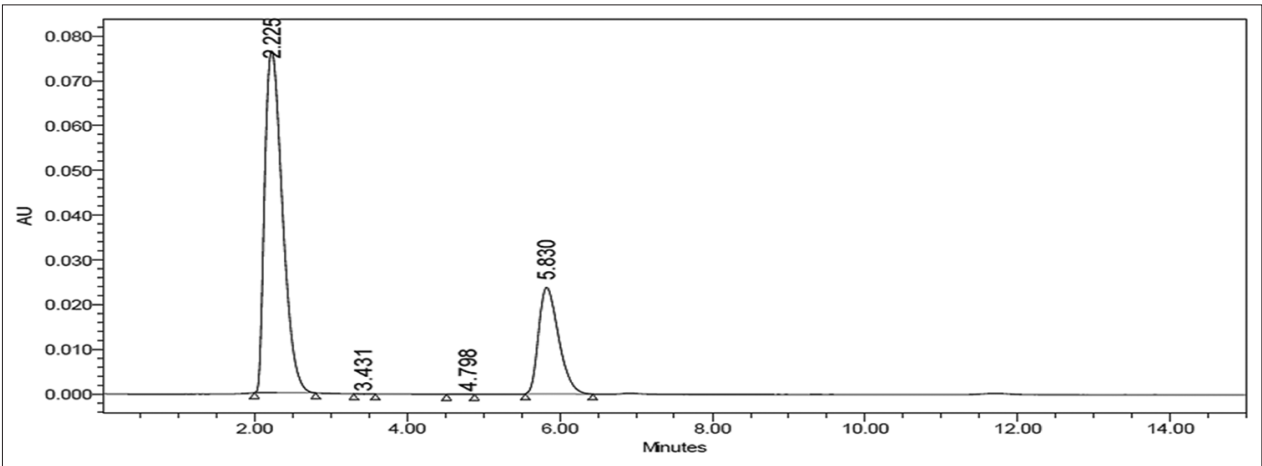

Fig. 15: Oxidative degradation

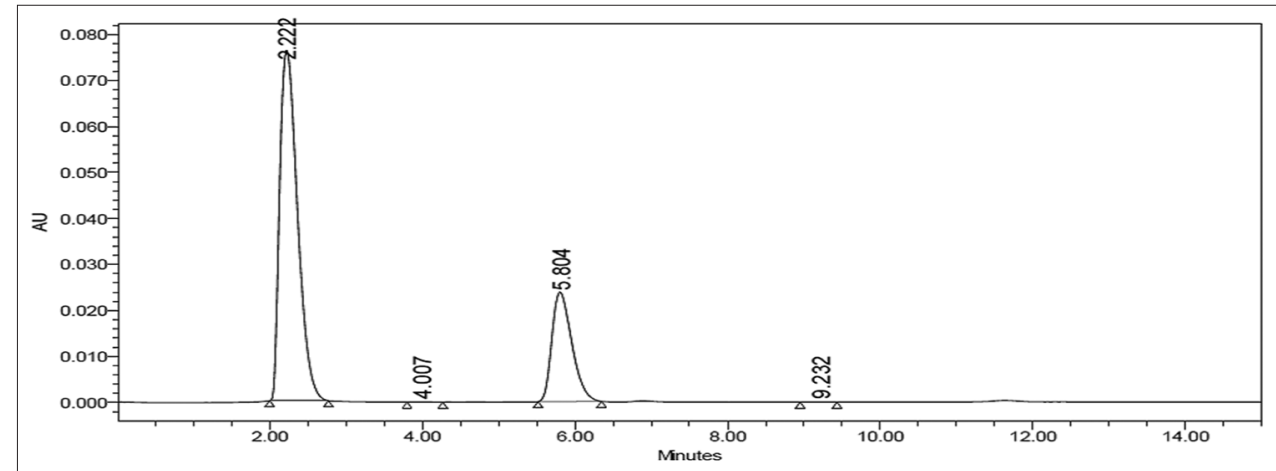

Fig. 16: Photolytic degradation

The obtained results for this method validation are within acceptance criteria. This method was more economical and stable. This method could selectively quantify metoprolol and atorvastatin in a pharmaceutical tablet dosage form. From the obtained experimental data, the developed method is more accurate, precise, and selective, so this method was suitable for routine analysis successfully for this 
combination in its bulk and marketed formulations by RP-HPLC using biorelevant dissolution media (FaSSIF).

\section{REFERENCES}

1. Schäfer M, Frischkopf K, Taimor G, Piper HM, Schlüter KD. Hypertrophic effect of selective beta(1)-adrenoceptor stimulation on ventricular cardiomyocytes from adult rat. Am J Physiol Cell Physiol 2000;279:C495-503.

2. Ladage D, Schwinger RH, Brixius K. Cardio-selective beta-blocker: Pharmacological evidence and their influence on exercise capacity. Cardiovasc Ther 2013;31:76-83.

3. Staudt A, Mobini R, Fu M, Grosse Y, Stangl V, Stangl K, et al. Beta(1)adrenoceptor antibodies induce positive inotropic response in isolated cardiomyocytes. Eur J Pharmacol 2001;423:115-9.

4. Pacanowski MA, Gong Y, Cooper-Dehoff RM, Schork NJ, Shriver MD, Langaee TY, et al. Beta-adrenergic receptor gene polymorphisms and beta-blocker treatment outcomes in hypertension. Clin Pharmacol Ther 2008;84:715-21.

5. Liu J, Liu ZQ, Tan ZR, Chen XP, Wang LS, Zhou G, et al. Gly389Arg polymorphism of beta1-adrenergic receptor is associated with the cardiovascular response to metoprolol. Clin Pharmacol Ther 2003;74:372-9.

6. Jafari M, Ebrahimi R, Ahmadi-Kashani M, Balian H, Bashir M. Efficacy of alternate-day dosing versus daily dosing of atorvastatin. J Cardiovasc Pharmacol Ther 2003;8:123-6.

7. Baxter JD, Webb P, Grover G, Scanlan TS. Selective activation of thyroid hormone signaling pathways by GC-1: A new approach to controlling cholesterol and body weight. Trends Endocrinol Metab 2004; 15:154-7.

8. Maejima T, Yamazaki H, Aoki T, Tamaki T, Sato F, Kitahara M, et al. Effect of pitavastatin on apolipoprotein A-I production in hepG2 cell. Biochem Biophys Res Commun 2004;324:835-9.

9. Bösel J, Gandor F, Harms C, Synowitz M, Harms U, Djoufack PC, et al. Neuroprotective effects of atorvastatin against glutamateinduced excitotoxicity in primary cortical neurones. J Neurochem 2005;92:1386-98.

10. Chen X, Ji ZL, Chen YZ. TTD: Therapeutic target database. Nucleic Acids Res 2002;30:412-5.

11. Snyder LR, Kirkland JJ, Dolan JW. Introduction to Modern Liquid Chromatography. $3^{\text {rd }}$ ed. Hoboken, New Jersey: Wiley Publishers; 2010.

12. Sangshetti JN, Aqeel M, Zaheer Z, Ahmed RZ, Dehghan MH, Gonjari I. Development and validation of RP-HPLC method for determination of atorvastatin calcium and nicotinic acid in combined tablet dosage form. J Saudi Chem Soc 2016;20:S328-33.

13. Peraman R, Mallikarjuna S, Ammineni P, Kondreddy VK. RP-HPLC method development and validation for simultaneous estimation of atorvastatin calcium and pioglitazone hydrochloride in pharmaceutical dosage form. J Chromatogr Sci 2014;52:1038-42.

14. Kurakula M, Sobahi TR, El-Helw AM, Abdelaal MY. Development and validation of an RP-HPLC method for assay of atorvastatin and its application in dissolution studies on thermosensitive hydrogel-based nanocrystals. Trop J Pharm Res 2014;13:1681-7.

15. Sharma R, Khanna S, Mishra GP. Development and validation of RP-HPLC method for simultaneous estimation of ramipril, aspirin and atorvastatin in pharmaceutical preparations. E-J Chem 2012;9:2177-84.

16. Jain N, Raghuwanshi R, Jain D. Development and validation of RPHPLC method for simultaneous estimation of atorvastatin calcium and fenofibrate in tablet dosage forms. Indian J Pharm Sci 2008;70:263-5.

17. Raul SK, Aravelli AB, Jhansi D. RP-HPLC method development and validation for the simultaneous estimation of atorvastatin and ezetimibe in pharmaceutical dosage form. Asian J Pharm Clin Res 2015;8:178-81.

18. Mawazi SM, Reddy GN. Method development and validation for simultaneous estimation of atorvastatin and ezetimibe in pharmaceutical dosage form by HPLC. World J Pharm Sci 2014;2:866-70.

19. Kumar SA, Debnath M, Rao JV, Sankar DG. New validated stabilityindicating rp-HPLC method for simultaneous estimation of atorvastatin and ezetimibe in human plasma by using PDA detector. Adv Pharm Bull 2015;5:385-91

20. Pryanka J, Mukesh K. Development and validation of a reverse phase HPLC method for the simultaneous estimation of metoprolol and telmisartan in tablet dosage form. Pharm Sin 2011;2:211-9.

21. Venkateswararao L, Vardhan SV, Venkatrao SV, Chintala R. Validated RP-HPLC method for the estimation of metoprolol succinate in dosage formulations. Am J Pharmtech Res 2013;3:328-34.

22. Nilesh J, Kumar SB, Ruchi J, Kumar JD, Surendra J. RP-HPLC method development and validation for quantitative estimation of metoprolol succinate and telmisartan in bulk drug and their dosage forms. J Pharm Biomed Sci 2012;24:102-6.

23. Brijesh S, Patel DK, Ghosh SK. Development of reverse-phase HPLC method for simultaneous analysis of metoprolol succinate and hydrochlorothiazide in a tablet formulation. Trop J Pharm Res 2009;8:539-43.

24. Tsvetkova BG, Pencheva IP, Peikov PT. Development and validation of RP-HPLC method for simultaneous determination of metoprolol and aspirin in fixed dose combinations. Pharm Chem 2012;4:1512-6.

25. Pokala M, Rani PJ, Pranathi G, Haque MA, Sireesha D, et al. Development and validation of rp-hplc method for the simultaneous estimation of amlodipine and metoprolol in bulk and pharmaceutical dosage form. Indo Am J Pharm Res 2015;5:3254-60.

26. Madhukar A, Kannappan N. RP-HPLC method for the simultaneous estimation of cilnidipine and metoprolol succinate in bulk and tablet dosage form in biorelevant media (FaSSIF). Int $\mathrm{J}$ Pharm Tech Res 2015;7:172-84.

27. Marques M. Dissolution media simulating fasted and fed states. Dissolut Technol 2004;11:16

28. Nitin BB, Adhikrao VY, Sachin SM, Rohan AK, Ashok AH, Sachin SS, et al. A review on development of biorelevant dissolution medium. J Drug Deliv Ther 2014;4:140-8.

29. Sharma MK. Bio-relevant dissolution media development. J Bioequiv Availab 2016;9:1-2.

30. Kostewicz ES, Brauns U, Becker R, Dressman JB. Forecasting the oral absorption behavior of poorly soluble weak bases using solubility and dissolution studies in biorelevant media. Pharm Res 2002;19:345-9.

31. Dressman JB, Reppas C. In vitro-in vivo correlations for lipophilic, poorly water-soluble drugs. Eur J Pharm Sci 2000;11 Suppl 2:S73-80.

32. ICH. Validation of Analytical Procedures: Text and Methodology Q2 (R1). International Conference on Harmonization; 2005. 